\title{
THE COSA MITHRAEUM: A LONG OVERDUE SURVEY
}

\begin{abstract}
Summary: Very likely due to its modest nature, the Cosa Mithraeum has been mentioned in scholarly publications only four times - each in passing - since its discovery in 1954. This sparse attention, restricted solely to literature on Cosa, has meant that the mithraeum is well-known among those intimately familiar with the colony, but has languished in complete obscurity among Mithraic scholars for the past half century. In addition to bringing the Cosa Mithraeum to the attention of a wider audience, this article also argues for a re-evaluation of the most recent dating of the mithraeum. Recent advances in scholarship on mithraea at Ostia give ample reason to suggest that the original date for the Cosa Mithraeum might be more accurate than later interpreters have assumed. Furthermore, the ongoing excavations of Cosa's bath complex, conducted by Florida State University, Bryn Mawr College, and Tübingen University have revealed a city that was still quite active during the 2nd century CE. In light of these developments, this article is an overdue study of the Cosa Mithraeum and its role in the history of the colony.
\end{abstract}

Key words: Cosa, Ostia, mithraeum, Mithraism, Roman baths, Roman colonies

Cosa, a Roman colony founded in $273 \mathrm{CE}$ about $140 \mathrm{~km}$ northwest of Rome, has a mithraeum. Although this mithraeum has been - in some sense - published, very few outside of those who are familiar with Cosa are aware of its existence. By "published", I mean that since its initial discovery and identification as a mithraeum in 1951 , it has been mentioned in passing in four publications discussing other topics regarding the Roman colony. ${ }^{1}$ With the help of a grant from the Institute for the Study of Antiquity and Christian Origins at the University of Texas at Austin, and in conjunction with the current excavations conducted by Florida State University, Bryn Mawr College, and Tübingen University, the area of the mithraeum was cleaned and

${ }^{1}$ Richardson, L.: Cosa and Rome. Archaeology 10.1 (1957) 49-55; Collins-Clinton, J.: A Late Antique Shrine of Liber Pater at Cosa [EPRO 64]. Leiden 1977; BROWN, F. E. - RICHARDSON, E. H. RICHARDSON, L.: Cosa III: The Buildings of the Forum [MAAR 37]. Ann Arbor 1993; and FENTRESS, E.: Settlement between the Third and Fifth Centuries AD. In FenTRESS, E. - BODEL, J. - BUTTREY, T. V. ET AL.: Cosa V: An Intermittent Town, Excavations 1991-1997 [MAAR 2]. Ann Arbor 2003, 63-71. 
partially re-excavated during the excavation season of 2015 in the hopes of shedding a little more light on a rarely discussed facet of Cosa's history. This paper has two goals. The first goal is to bring this mithraeum to the attention of the larger community of Mithraic scholarship. The second goal is to reassess the most recent date given to the Cosa Mithraeum in the latest volume of excavation reports from the site, published in 2003 (one of the four passing mentions of the mithraeum). In what follows, I will provide a brief history of the discovery of the mithraeum during the earliest excavations. Next, I will discuss the excavations of Cosa in the 1990's, and how the subsequent report shifted the dating of the mithraeum. I will then move to an overview of the present excavations in the bath complex at Cosa, which has yielded some interesting finds regarding the date of the mithraeum. Finally, I will briefly discuss comparanda at Ostia, with an eye toward arguing in favor of the date provided by the original excavators.

Excavations at Cosa began in 1948 as the flagship dig of the American Academy in Rome under the direction of Frank Brown. The earliest excavations focused on the temples of the arx and the buildings of the forum, where the mithraeum is located. Since these earliest excavations, many of Cosa's structures, including its massive walls and Capitolium, have become examples par excellence of Republican architecture. $^{2}$

During the excavations of the summer of 1951, Brown and his associates turned their attention to the forum. Lawrence Richardson, Brown's student at the time, oversaw the forum excavations of the curia and comitium complex, which he initially referred to as "Building C". ${ }^{3}$ The tell-tale circular shape of the comitium led Richardson to conclude that the attached rear building was the corresponding curia. But on June 5th of that season, while digging in what Richardson had labelled the fourth stratigraphic unit of the building, he discovered a pair of benches lining opposite walls, made of unmortared stone and filled with rubble and dirt. "Is this a mithraeum?" Richardson tentatively asked in his excavation log. Further discoveries, to be discussed momentarily, confirmed his hypothesis.

Richardson's mithraeum is located in the basement of the curia, which, together with the comitium, constitutes the earliest structures in Cosa's forum. The pair of connected buildings was built shortly after Cosa's founding in $273 \mathrm{BCE}^{4}$ (fig. 1). The earliest phase of the present curia consisted of a single, two-story room on axis with the comitium, built with the same large, polygonal limestone blocks that comprise Cosa's walls. The building was built on the side of a slope beside the comitium, meaning that the entrance to the building was on the second floor, facing the comitium (SW). The lower floor would have been accessed by stairs, and was likely used for the keeping of records. ${ }^{5}$

\footnotetext{
${ }^{2}$ See, for instance, Ramage, N. H. - Ramage, A.: Roman Art: Romulus to Constantine. 1 st ed. New York 1991, 74.

${ }^{3}$ Brown, F. E.: Cosa I: History and Topography [MAAR 21]. Ann Arbor 1951, 78-80.

${ }^{4}$ BROWN-RICHARDSON-RICHARDSON (n. 1) 11-30.

${ }^{5}$ BROWN-RICHARDSON-RICHARDSON (n. 1) 28-30.
} 


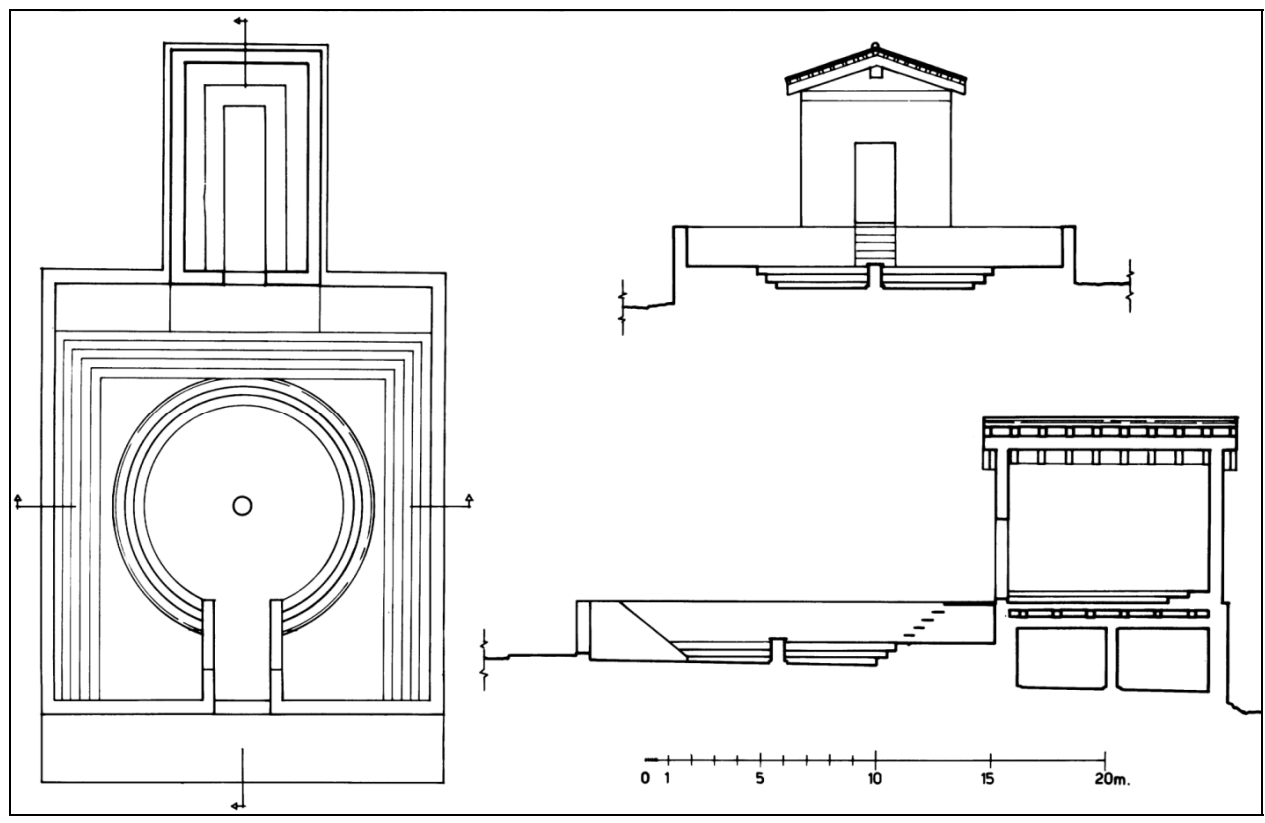

Fig. 1. The original curia and comitium, ca. $273 \mathrm{BCE}$ (courtesy of BROWN-RICHARDSON-RICHARDSON [n. 1] 27)

In $197 \mathrm{BCE}$, a second wave of colonists arrived, leading to substantial renovations of the complex. Between 175 and $150 \mathrm{BCE}$, the original, single room curia was replaced by one with three chambers (fig. 2). These new wings shared their inner walls with the original structure, but were expanded with walls of mortared rubble. Like the original central structure, both of these additions contained two stories. The basements were floored with rammed earth, while wood beams in the ceilings provided support for the floors above. The second stories of the two new wings were accessed, like the central hall, through doorways that opened to the comitium. ${ }^{6}$ In his description of this phase, Richardson admits that it was unclear whether or not these new rooms communicated with one another via internal doorways. ${ }^{7}$ Richardson further suggests that during the Republican and early imperial periods, these new additions may have served as offices for the duumviri and aediles of the colonia. ${ }^{8}$

The installation of the mithraeum in the basement of the structure marks the final phase of renovations. The dating of these renovations has been the subject of some debate, and will be addressed momentarily. Aside from the rubble-filled benches mentioned previously, Richardson also found small niches in either bench lined with roof tiles (no longer extant), as well as large blocks of brick and mortar constructed within each bench, possibly for supporting statues (fig. 3). Another base was found at

\footnotetext{
${ }^{6}$ BROWN-RICHARDSON-RICHARDSON (n. 1) 139-142.

${ }^{7}$ RICHARDSON (n. 1) 53-44.

${ }^{8}$ RICHARDSON (n. 1) 55.
} 


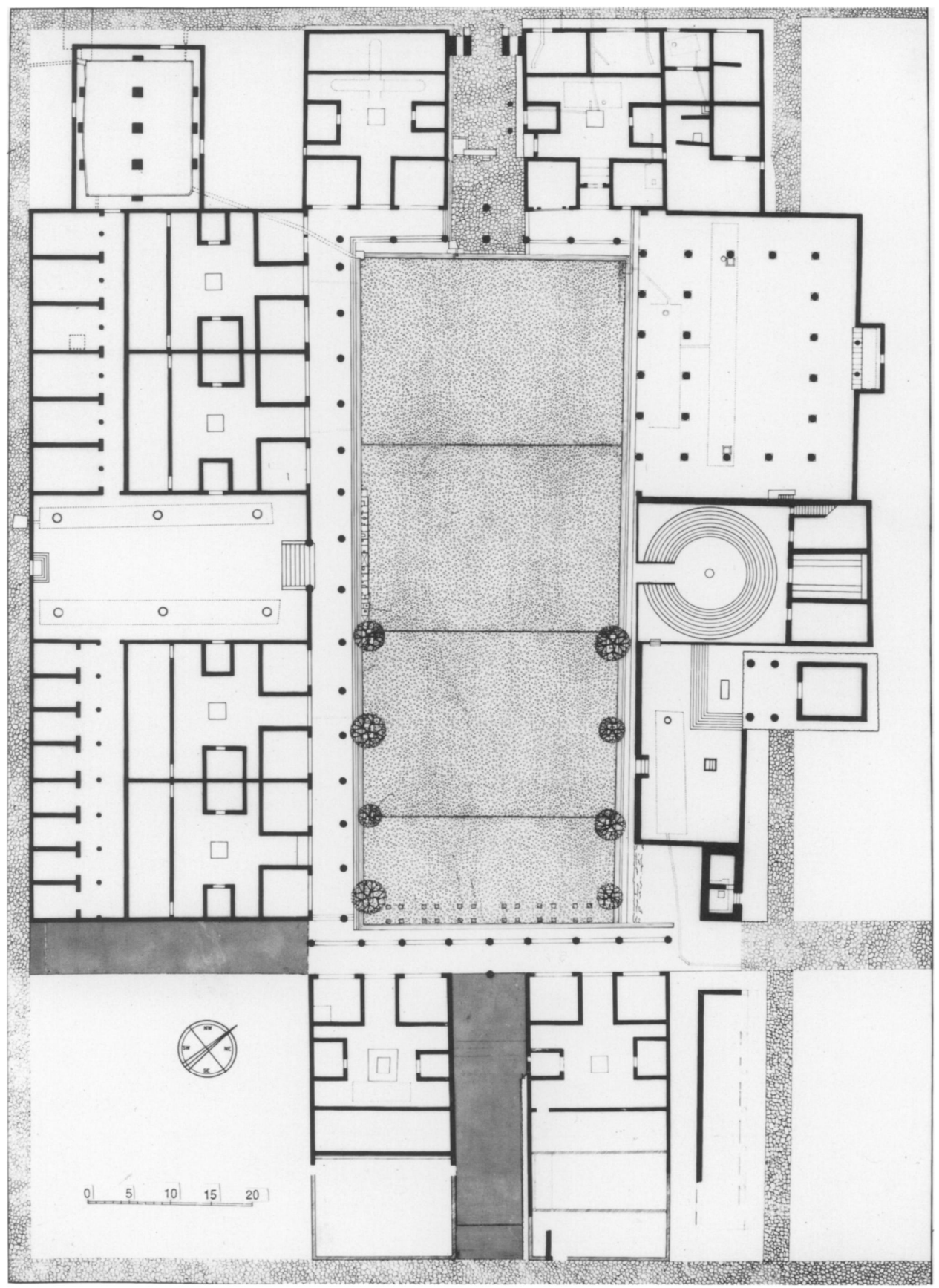

Fig. 2. The forum, with comitium and expanded curia on north east side, ca. 140 BCE (courtesy of BROWN-RICHARDSON-RICHARDSON [n. 1] 130) 


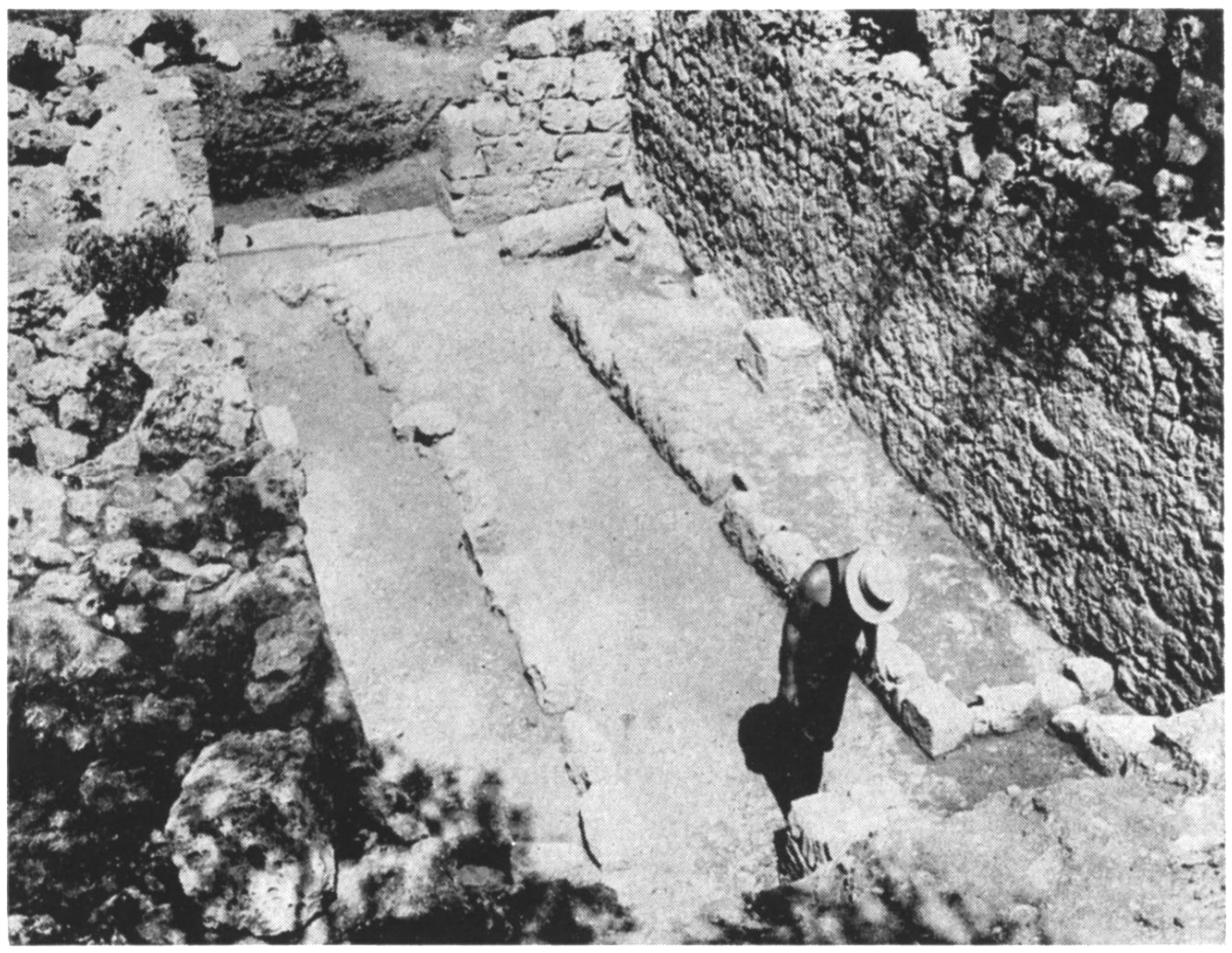

Fig. 3. The Cosa Mithraeum after the original excavation (courtesy of RICHARDSON [n. 1] 54)

the end of the SE bench, and another in the western corner of the room. At the rear of the room, about $70 \mathrm{~cm}$ from the rear wall, Richardson found an "altar", $60 \mathrm{~cm}$ on either side, and $1.2 \mathrm{~m}$ high, of similar construction to the two blocks in the benches. On the ground in front of this altar is a "ritual" well lined with mortar. Richardson found traces of plaster lining the rear wall behind the altar, some of which is still extant half a century later. He suggested that the plaster comprised part of a frescoed tauroctony that matched the modest nature of the small room. ${ }^{9}$

Finds from this final stage of the curia basement included five bronze coins dating from $164 \mathrm{CE}$ to $241 \mathrm{CE}$, from the reigns of Lucius Verus to Gordian III, as well as eleven lamps, all of which are of a style in use no later than $400 \mathrm{CE}$, according to Fitch and Goldman. ${ }^{10}$ One of these lamps bears the image of youth wearing a solar crown (fig. 4). Near the base at the end of the SE corner, excavators found the

\footnotetext{
${ }^{9}$ RICHARDSON (n. 1) 55.

${ }^{10}$ BROWN-RICHARDSON-RICHARDSON (n. 1) 245. For the coins, see ButTREY, T. V.: Cosa: The Coins [MAAR 34]. Ann Arbor 1980, 48-50, inv. nrr CG 405, CG 407, CG 409, CG 410, and CG 417. For the lamps, see FITCH, C. R. - GoldmAn, N. W.: Cosa: The Lamps [MAAR 39]. Ann Arbor 1994, inv. nrr CG 281, CG 282, CG 284, CG 286, CG 304, CG 315, published in FiTCH-GoldMAN as 1007, 1008, $1066,1079,1059,805$, respectively. Two of the lamps from the Mithraeum, inv. nrr CG 283 and CG 285, were not published by FITCH-GOLDMAN.
} 


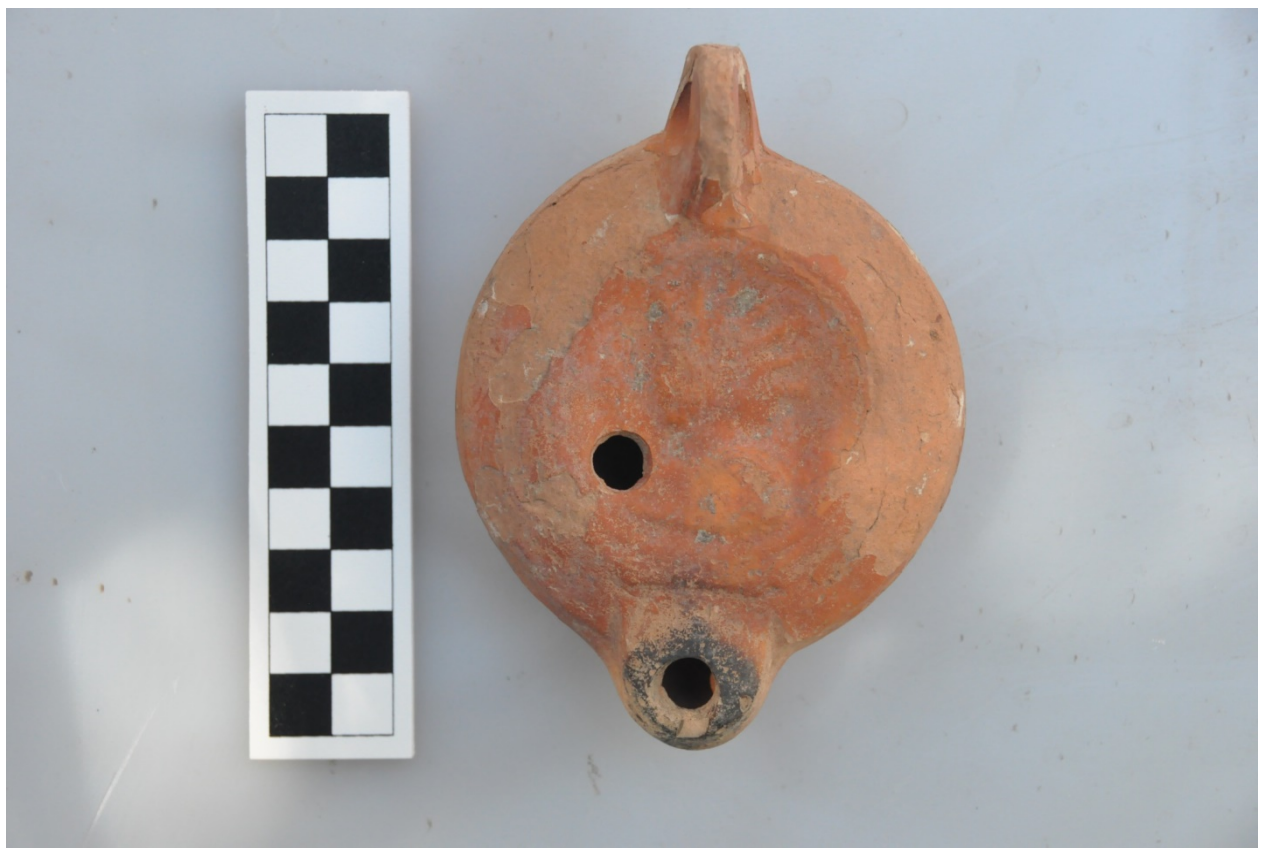

Fig. 4. Lamp featuring profile of youth with solar crown (photo courtesy of author)

calf and ankle of a marble statue. The architecture, combined with the finds, led Richardsons and Brown to date the mithraeum at Cosa to the mid-2nd century. ${ }^{11}$

Sometime during the 1990's, following the publication of the aforementioned leg fragment, Dr. Jacquelyn Collins-Clinton identified a foot, found during the original excavations in Temple B (next to the mithraeum), as belonging to the leg fragment. The shape of the foot suggests that it is the right one (not the left) (figs 5 and 6). The rear of the leg and the bottom of the foot are both unfinished, further suggesting that this leg was meant to stand upright. Although Richardson suggested that it might have belonged to Mithras himself, I would argue that, if this statue was indeed part of the mithraeum's decorative scheme, it would more likely have belonged to Cautes or Cautopates. Given their iconic cross-legged stance, this leg may have been the straight leg bearing the weight of the statue, while the other lay diagonally across it. A figure in such a pose, with insufficient support, would have easily broken just below where the legs cross, as is the case with a figure of unidentified Roman origin published in Vermaseren's catalogue of Mithraic monuments (fig. 7). ${ }^{12}$

A new series of excavations at Cosa began in the 1990's under the direction of Elizabeth Fentress. The primary conclusion from these excavations, as reflected in

${ }^{11}$ BROWN-RICHARDSON-RICHARDSON (n. 1) 244 and plate 258.

${ }^{12}$ Vermaseren, M. J.: Corpus Inscriptionum et Monumentorum Religionis Mithriacae [CIMRM]. Vol. I. Leiden 1956, 202, monumentum \#505, fig. 146. 


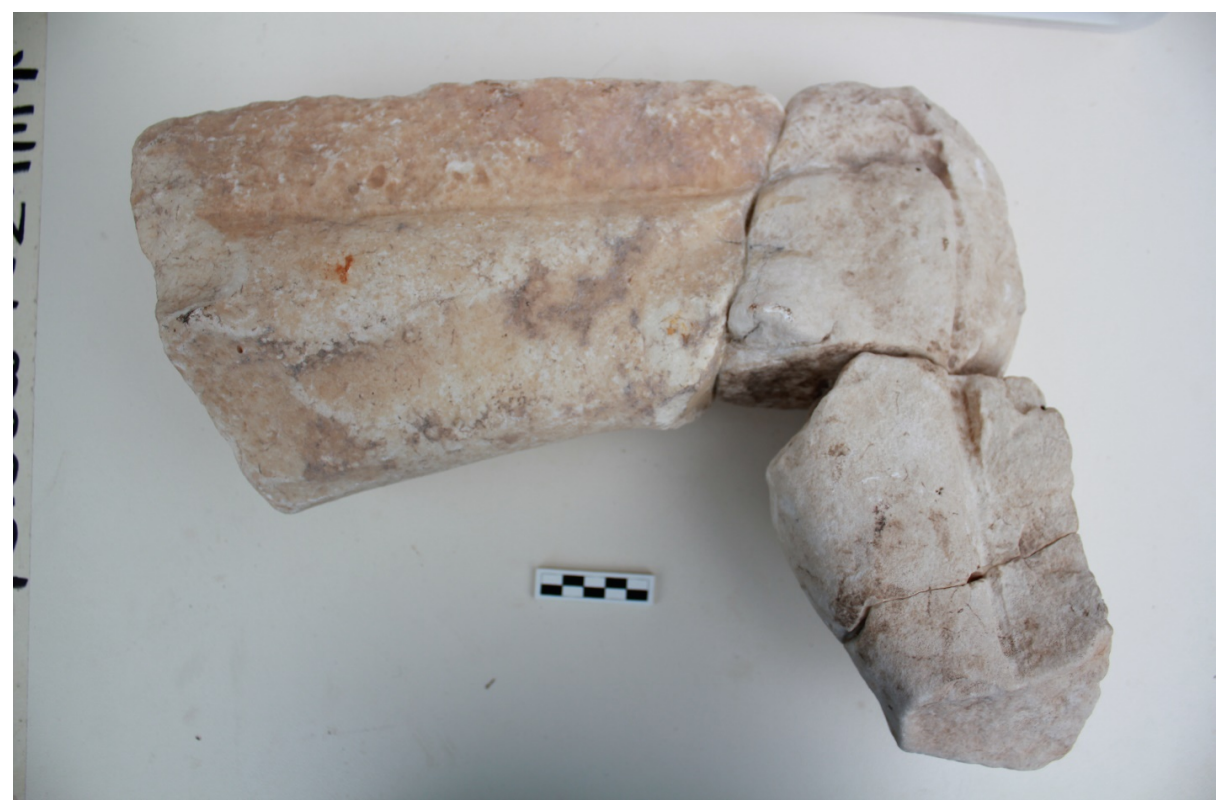

Fig. 5. Leg fragment joined with foot (photo courtesy of Matthew Brennan)

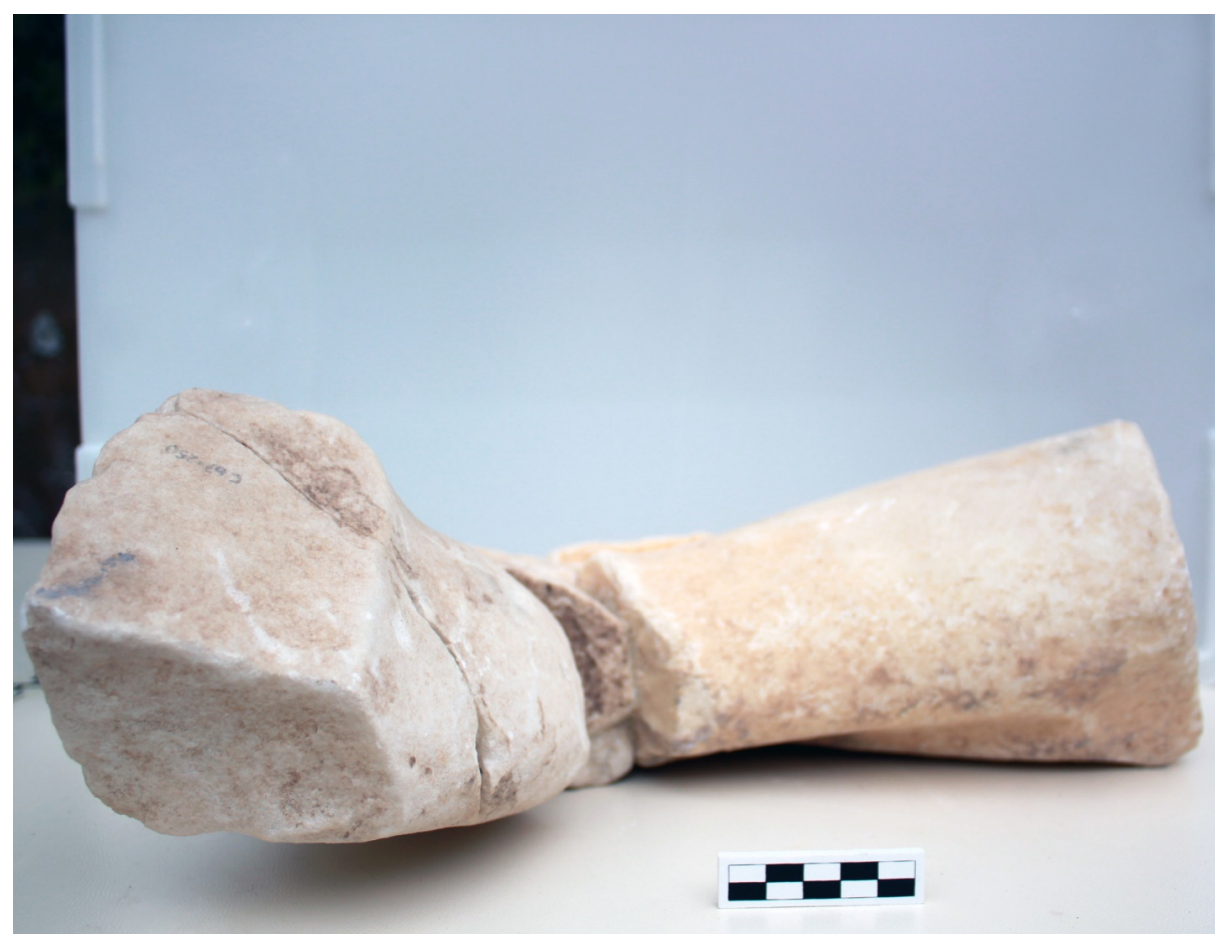

Fig. 6. Leg fragment joined with foot, anterior view (photo courtesy of Matthew Brennan) 


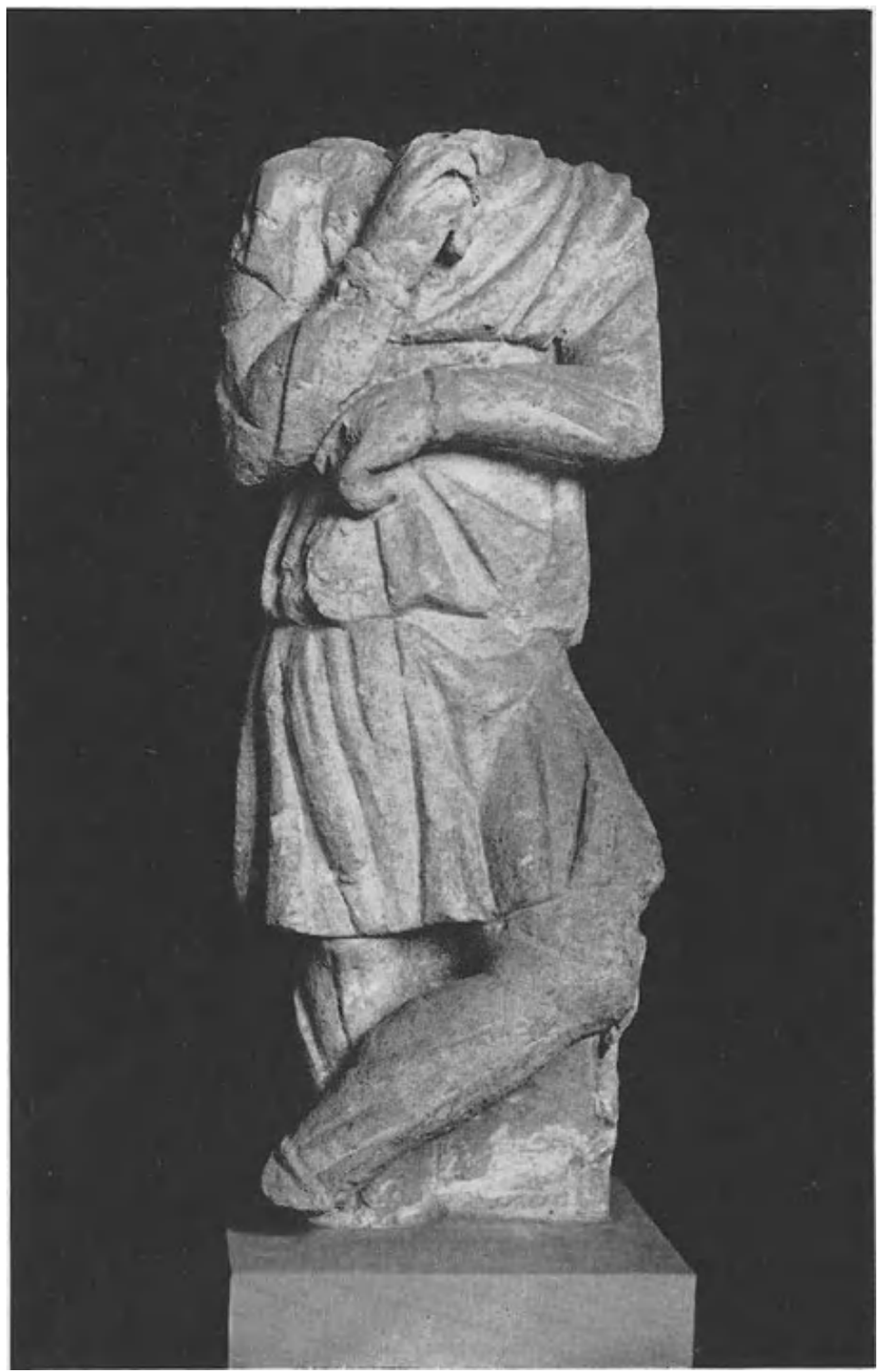

Fig. 7. Cautes or Cautopates (photo courtesy of CIMRM 202, monumentum \#505, fig. 146)

the title of their publication, Cosa $V$ : An Intermittent Town, was that Cosa's story was one of repeated abandonment and resettlement over the course of the centuries. Fentress identified six waves of settlement between Cosa's initial founding in 273 BCE and the end of the 10 th century. ${ }^{13}$ The various building phases of elite housing in Cosa

${ }^{13}$ FentRESS (n. 1) 138-139. 
play a central role in the narrative Fentress constructs, in which the city is mostly abandoned by the late 1 st century CE. Archaeological evidence for an imperial effort to reinvigorate the city during the reign of Caracalla, in Fentress' view, are more likely part of an elaborate fiction to keep the res publica Cosanorum alive on paper to allow a select few curators to maintain and take advantage of the public lands belonging to the colonia. ${ }^{14}$ 2nd-century Cosa, according to Fentress, was little more than a Potemkin village. One of the many casualties of this new narrative is the mithraeum, which received a new date of the mid-to-late 3rd century $\mathrm{CE}$. Fentress bases this re-dating on two major points: the first being that the settlement shows little activity during the mid-to-late 2nd century (Brown and Richardson's dating), and the second being that mithraea do not appear in public buildings at Ostia until the 3rd century, whereas mithraea at Ostia contemporary to Richardson and Brown's dating appear only in private houses. $^{15}$

The most recent excavations at Cosa, a joint project between Florida State University, Bryn Mawr College, and Tübingen University, began in 2013, under the direction of Andrea Di Georgi and Russell "Darby" Scott. These excavations, still ongoing, have focused primarily on a previously unexcavated bath complex, originally identified as such by Frank Brown during the earliest excavations of the mid-20th century. ${ }^{16}$ Results of the 2013 season were published in 2015. ${ }^{17}$ Most notable among the finds from the baths were nine stamped bricks. Two bricks from the laconicum of the bath complex bear the stamp of the figlinae Oceanae Maiores, a major Roman brick manufacturer, and the name of the officiator, Q. Perusius Pudens. Attestations of this brick manufacturer and its officiator elsewhere provide a date between 138 and $148 \mathrm{CE}$ for the bricks found in the baths at Cosa. ${ }^{18}$ Bricks from the same figlinae Oceanae Maiores, dating to the 160's CE, were also found in the earlier excavations of Cosa's arx. ${ }^{19}$ Another set of three stamped bricks from the bath complex were manufactured by the workshop owned by Domitia Lucila and provide a date of $145 \mathrm{CE}$. Both brick manufacturers were prominent within their industry, and their products are well attested in and around Rome. Finally, an inscription possibly referring to Caracalla was also found during the 2013 season. $^{20}$ The results of the 2013 season, and those of the subsequent years, have provided strong evidence in favor of continued growth and activity in Cosa during the 2 nd century. Such activity was not limited to the local level, however, as it appears that Cosa continued to interact with, and perhaps even receive favors from, the imperial capital. Such findings bring the narrative of decline previously proposed by Fentress into question. Why renovate and maintain

${ }^{14}$ FENTRESS (n. 1) 66-67.

${ }^{15}$ FENTRESS (n. 1) 65-66.

${ }^{16}$ BROWN (n. 3) 82-88.

${ }^{17}$ SCOTT, R. T - De GiORgI, A. U. ET AL: Cosa Excavations: The 2013 Report. Orizzonti: Rassegna di archeologia 16 (2015) 11-22.

${ }^{18}$ SCOTT-DE GIORGI (n. 17) 17.

${ }^{19}$ SCOTT - De GIORGi (n. 17) 17; see also the dissertation of BACE, E. J.: Cosa: Inscriptions on Stone and Brick-stamps. University of Michigan 1983.

${ }^{20}$ SCOTT - DE GIORGI (n. 17) 18. 
a bath complex for a nearly empty city? These findings are worth considering when dating the Cosa Mithraeum. It is also worth noting that the bath complex sits atop a large, vaulted underground cistern, from which it drew its water. ${ }^{21}$ Had the baths fallen out of use during a period of decline, this vaulted cistern would have made a much more ideal locale for a mithraeum, much like the mithraeum built beneath the Baths of Mithras at Ostia. ${ }^{22}$ As it stands, however, recent preliminary soundings in the cistern beneath the bath complex reveal that it was not until the medieval period, at the earliest, that the cistern was converted for a different use (probably as seasonal shelter for local shepherds). We must therefore conclude that by the time the mithraists of Cosa sought a suitable gathering place, the cistern was still in use by the baths above.

Secondly, Fentress bases her dating of Ostian mithraea, to which she compares the mithraeum at Cosa, on the work of Giovanni Becatti, whose chronology has undergone some modification by subsequent scholars since it was originally published in $1954 .^{23}$ The recent work of L. Michael White, for instance, has pushed Becatti's dating of the Mithraeum of the Animals (160's CE) back by about thirty years, to the end of the 2 nd century. ${ }^{24}$ While Fentress' claim that the earliest mithraea in Ostia were found in private houses still holds true (the Pareti Dipinti and Sette Sfere mithraea, for instance), the ambiguity of the distinction between the concepts of private and public when referring to ancient structures weakens Fentress' overall argument. The subsequent five 2nd-century Ostian mithraea in White's chronology (Sette Porte, Fagan, Animale, Aldobrandini, and Palazzo Imperiale) are all modifications of nondomestic structures, or combinations between domestic and non-domestic structures, where the "private/public" qualities are less easily defined. ${ }^{25}$ The Aldobrandini Mithraeum, for instance, was built to share a wall with the wall of the city. ${ }^{26}$ By the mid2nd century, then, Ostian mithraea had already moved beyond the confines of private homes, and a date after the second half of the 2 nd century for the mithraeum at Cosa is not necessarily as far-fetched as Fentress argues. Furthermore, the continued contact with Rome throughout the 2nd century would lend credence to the idea that the religious trends taking place in Ostia were also occurring in Cosa.

Following the original excavations, only the small ritual well located toward the rear of the room was reburied by the excavators; the rest of the mithraeum was left as they had found it. Unfortunately, during the intervening sixty years, nature had reclaimed many of the areas adjacent to the forum that were less frequented by tourists,

${ }^{21}$ BROWN (n. 3) 84.

${ }^{22}$ CIMRM 118, monumentum \#229.

${ }^{23}$ BECATTI, G.: Scavi di Ostia. II: I Mitrei. Roma 1954.

${ }^{24}$ WHITE, L. M.: The Changing Face of Mithraism at Ostia: Archaeology, Art, and the Urban Landscape. In BALCH, D. L. - WeISSENRIEDER, A. (eds): Contested Spaces: Houses and Temples in Roman Antiquity and the New Testament. Tübingen 2012, 491-492 and 445-450 for the Mithraeum of the Animals.

${ }^{25}$ WHITE (n. 24) 441-443 for chronological catalogue.

${ }^{26}$ WHITE (n. 24) 441; CIMRM 119, monumentum \#232. 


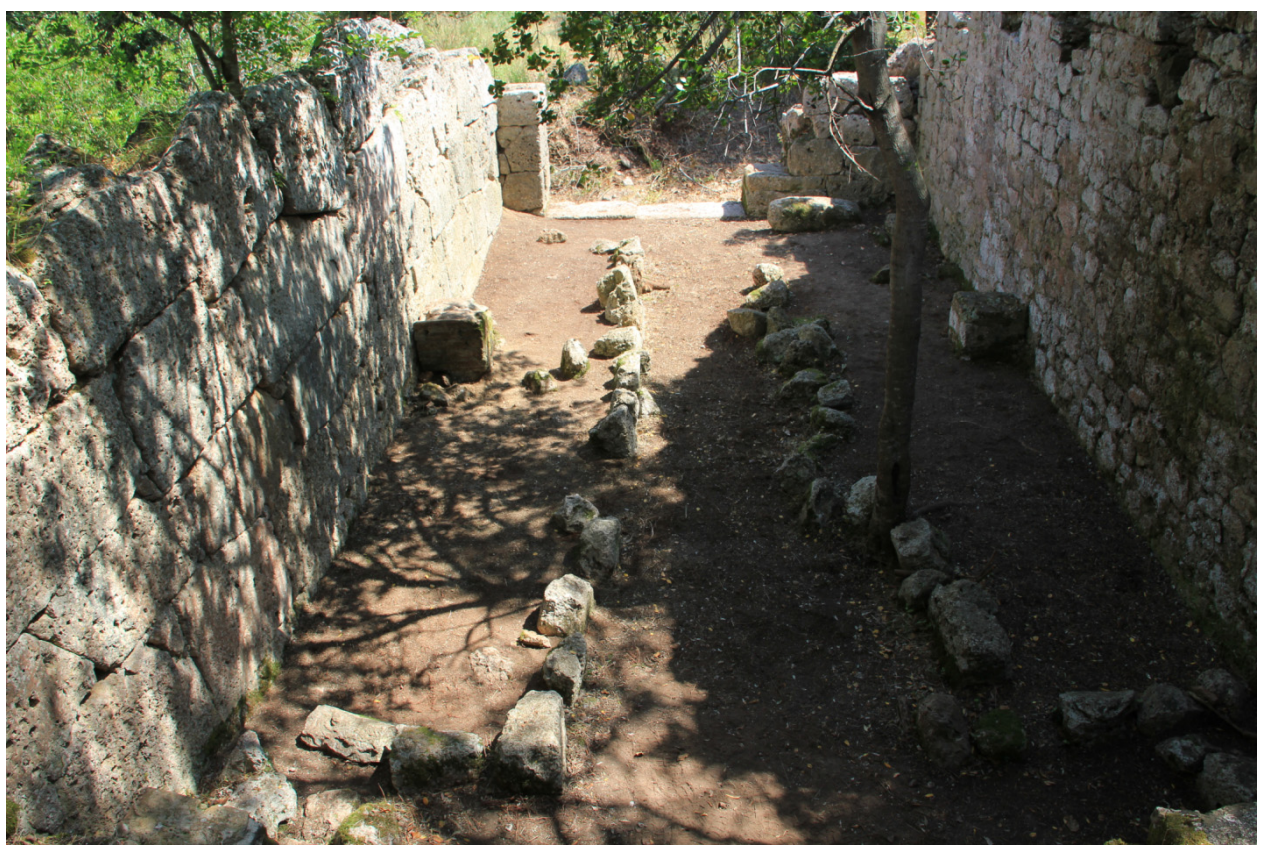

Fig. 8. View of mithraeum from SW, second story entrance, looking toward NE ground-floor entrance (photo courtesy of author)

and the mithraeum was no exception. At the beginning of our attempt to clean and photograph the mithraeum, my colleagues and I found that both the second-story northern entrance and the ground-level south-western entrance were entirely obstructed by vegetation. Once the vegetation had been removed, several things became apparent. First, the neatly arrayed rubble masonry outlines of the mithraeum's benches that had greeted Richardson during his initial excavation had since become uneven with time, with some rocks having disappeared altogether (fig. 8). The two niches in the centers of each outline that Richardson had identified were now completely unidentifiable. Second, the two brick and mortar blocks that previously sat opposite each other within each bench had now been moved toward the center of the aisle that separates the two benches. Both of these moved blocks were matched and returned to their original locations. Most shocking, however, was the fact that the altar that Richardson had described as sitting $70 \mathrm{~cm}$ from the rear wall had disappeared completely (fig. 9). Neither of the other two blocks fit the measurements of the altar, disconfirming the possibility that either one might in fact be the altar (but, even if one had been the altar, we would still be left wondering what had become of one of the blocks from the benches). On a positive note, however, the small ritual well that lay just beneath the vanished altar was still in place (fig. 10).

The goals of this paper, like the mithraeum it describes, were modest. As I initially stated, my primary intent was only to provide the wider community of Mithraic scholars with a long-overdue introduction to the Cosa Mithraeum. The second goal 


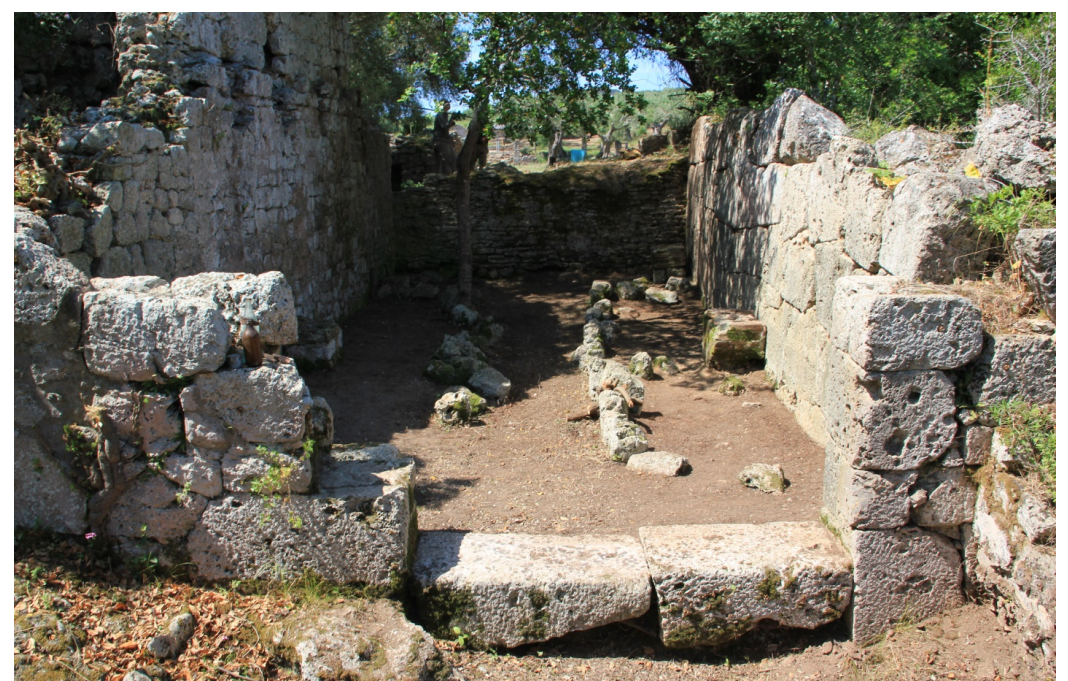

Fig. 9. View of mithraeum from NE entrance. Missing altar should be directly ahead, against rear wall (photo courtesy of author)

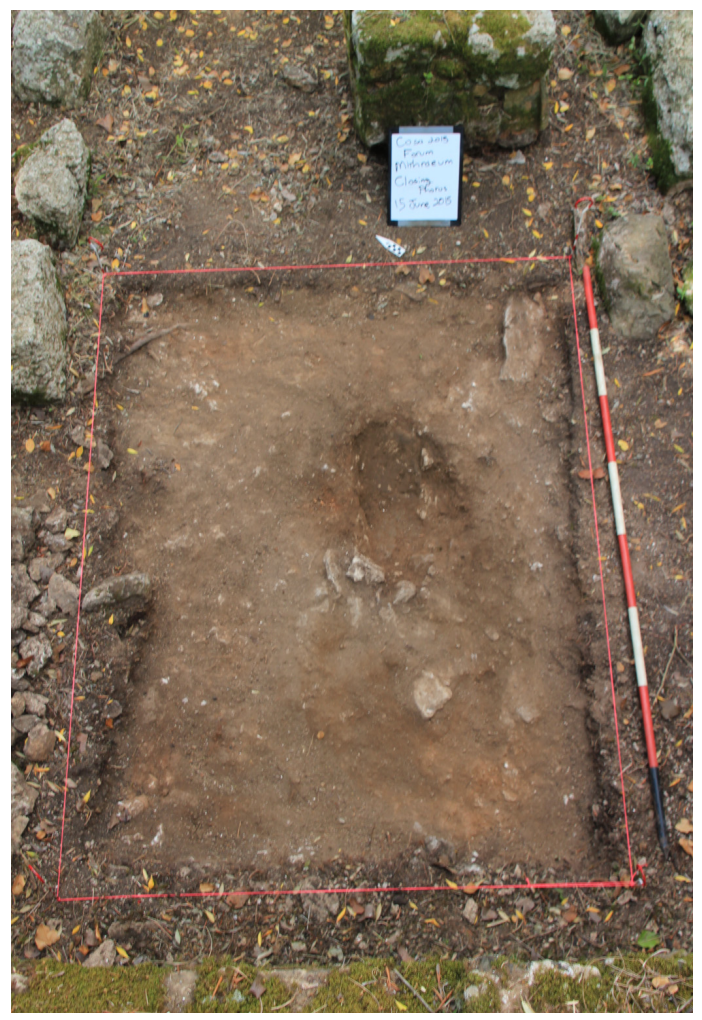

Fig. 10. "Ritual well" as viewed from atop SE rear wall (photo courtesy of author) 
was to reassess the dating of the mithraeum in light of the finds from the most recent excavations at Cosa. As we have seen, these excavations have provided more reason to believe that Cosa was still an active and inhabited community during the mid to late 2nd century CE than had previously been assumed. Given these developments, I argue, Richardson's earlier date for the mithraeum is indeed plausible and should not be discarded.

\author{
James C. Henriques \\ The University of Texas at Austin \\ USA \\ james.c.henriques@utexas.edu
}


